\title{
Studies on the redox reaction kinetics of selected, naturally occurring oxygen carrier
}

\author{
Ewelina Ksepko $^{1} \cdot$ Piotr Babinski $^{1} \cdot$ Antigoni Evdou $^{2} \cdot$ Lori Nalbandian $^{2}$
}

Received: 30 March 2015/ Accepted: 17 October 2015/Published online: 2 November 2015

(C) The Author(s) 2015. This article is published with open access at Springerlink.com

\begin{abstract}
This paper presents the results of a chemicallooping combustion (CLC) study. The CLC technology is believed to be one of the most promising combustion technologies. The production of a concentrated $\mathrm{CO}_{2}$ stream that is obtained after the water condensation without any loss of energy in its separation is one of the most crucial advantages of this technology. The objective of this work was to study the kinetics of both the reduction and oxidation reactions for naturally occurring oxygen carriers that show promising reactivity in CLC reactions, and might therefore be utilized as oxygen carrier materials. Kryvbas, a Fe-based ore, was selected for this analysis because it possessed sufficient concentrations of the active metal oxides (Fe oxide above $80 \%$ and traces of Mn oxide) and a high melting temperature that was above $1500{ }^{\circ} \mathrm{C}$. Experiments were conducted under isothermal conditions within the temperature range of $750-950{ }^{\circ} \mathrm{C}$ with multiple redox cycles using a thermogravimetric analyzer (TG). For the reduction and oxidation reactions, $\mathrm{CH}_{4}$ (at different concentrations) and air were used, respectively. The sample showed promising results where a sufficient reactivity was observed with the fuel, and these results were reproducible. Both fresh material and samples that were used in multiple redox cycles were characterized by $\mathrm{X}$-ray Diffraction
\end{abstract}

Ewelina Ksepko

eksepko@ichpw.pl

1 Institute for the Chemical Processing of Coal, 1 Zamkowa, 41-803 Zabrze, Poland

2 Center for Research and Technology Hellas/Chemical Process Engineering Research Institute, 6th km Harilaou Thermi Rd, P.O. Box 60361, 57001 Thermi, Thessaloniki, Greece
(XRD) and Scanning Electron Microscopy combined with X-ray Microanalysis (SEM-EDS) in order to detect any structural or morphological changes as well as to determine the stability of the ore in repetitive CLC cycles. Kinetic parameters, such as the activation energy, the preexponential factor, and the reaction model, were determined for the redox reactions. Models of the redox reactions were selected by using a model fitting method. The F1 model (volumetric) was a suitable model for the modeling of the Kryvbas ore reduction reaction kinetics. The calculated $E_{\mathrm{a}}$ was equal to $42.00 \mathrm{~kJ} \mathrm{~mol}^{-1}$, while the reaction order was determined to be equal to 1.98 . The best fit for the oxidation reaction was obtained for the $\mathrm{R} 3$ model (shrinking core model). The oxidation (regeneration) reaction activation energy was equal to $16.70 \mathrm{~kJ} \mathrm{~mol}^{-1}$, and the reaction order was determined to be equal to approximately 0.49 .

Keywords Reaction model - Kinetics - Kryvbas ore · Natural oxygen carriers for chemical-looping combustion . Methane

\section{Introduction}

The combustion of fossil fuels is one of the major sources of the emissions of carbon dioxide $\left(\mathrm{CO}_{2}\right)$ and nitrogen oxides $\left(\mathrm{NO}_{\mathrm{x}}\right)$ that are responsible for greenhouse gases being a significant contributor to the effects of global warming. Consequently, it is necessary to develop new combustion technologies for fossil fuels that promote a significant reduction both of $\mathrm{CO}_{2}$ and $\mathrm{NO}_{\mathrm{x}}$ emissions. Because existing $\mathrm{CO}_{2}$ capture technologies are both costly and highly energy intensive, new energy-efficient fuel combustion methods that produce high-purity $\mathrm{CO}_{2}[1,2]$, such as chemical-looping combustion (CLC), might be a 
possible solution. In CLC technology, an oxygen carrier (OC) was utilized; this OC is typically a metal oxide and it is responsible for the transportation of oxygen from the air to the fuel. Through the utilization of a metal oxide, direct contact between the fuel and air is avoided, and this has a significant implication on the lowering of the costs and the energy penalties in the power plant.

The chemical-looping combustion system consists of two reactors, namely an air reactor and a fuel reactor. In the fuel reactor, the fuel reacts with the oxygen that is released from the metal oxide structure. The reduced metal oxide and/or its metallic form is oxidized (regenerated) in the air reactor back to its metal oxide form. Afterward, the metal oxide can then be used in another reduction-oxidation cycle. One significant advantage of the CLC is that after the condensation of water, a pure stream of $\mathrm{CO}_{2}$ (not diluted by $\mathrm{N}_{2}$ ) can be obtained from the fuel reactor. Based upon that advantage, the CLC is one of the most encouraging combustion technologies with the production of a concentrated $\mathrm{CO}_{2}$ stream that is ready for sequestration without an additional energy penalty for its separation $[2,3]$.

The requirements for the practical utilization of oxygen carriers in a chemical-looping combustion power plant are: a high redox reactivity, a high degree of selectivity toward complete oxidation products, a sufficient stability under repeated reduction/oxidation cycles at high temperatures, high mechanical strengths associated with a high degree of circulation of the particles, the materials must be non-toxic, a low preparation cost, and a resistance to a buildup of carbon and sulfur, which could lead to the deactivation of the oxygen carrier [4, 5]. The identification of suitable candidates for their use as oxygen carriers in the CLC process is difficult due to the previously mentioned competing factors. In the past, most of the existing CLC literature focused on the development of simple suitable synthetic oxygen carrier materials, such as $\mathrm{NiO}$, $\mathrm{CuO}, \mathrm{Fe}_{2} \mathrm{O}_{3}, \mathrm{CoO}$, and $\mathrm{MnO}_{2}[5,6]$.

More recently, the literature has highlighted the potential use of more complex materials, such as perovskite-type oxides [7, 8], spinel-type oxides [9-12], and mixed-metal oxides [4, 13, 14]. However, these studies were limited.

Recently, some minerals [15-18] industry wastes [15] and other wastes $[19,20]$ have been considered as inexpensive oxygen carriers for the chemical-looping combustion. The reason for the use of the aforementioned oxygen carriers, which are derived from natural materials and are therefore significantly less expensive, is that it lowers the cost of the overall process. In order to determine which materials are suitable candidates for the oxygen carriers, the natural materials should also possess enhanced kinetics, they must be stable and highly reactive, they must have a good degree of mechanical stability, and they must exhibit higher methane or syngas conversion rates [15].
Successful examples of natural oxygen carriers have been found in some natural ores, such as an iron ore from Carajas, Malmberget or LKAB in [14], and a waste iron oxide that is a residual product from the rolling of steel sheets that consist mostly of $\mathrm{Fe}_{2} \mathrm{O}_{3}$ and $\mathrm{Fe}_{3} \mathrm{O}_{4}$, such as Glödskal A [14]. Several suitable low-cost Fe-based oxygen carriers have been identified [17] that exhibit higher syngas $\left(50 \% \mathrm{H}_{2} / 50 \% \mathrm{CO}\right)$ conversion rates than those rates that were obtained using ilmenite. Promising results were also obtained for sediments from potable water purification, which were composed mainly of $\mathrm{Fe}_{2} \mathrm{O}_{3}$ $(57.8-58.1 \%)$ [19]. The maximum oxygen transport capacity varied for these sediments, mainly from 4 to 13.9 mass \%. These sediments also demonstrated a stability in their crystalline structure and achieved complete regeneration, which was very rare among the naturally occurring oxygen carriers. It was concluded that it was possible that other elements may have helped to maintain its reactivity and prevented the formation of silicates. The brief overview presented here highlights the growing interest in the use of natural oxygen carriers [14, 17, 21].

The rates of the redox reactions of the oxygen carriers with the fuel, the metal oxide oxygen transfer capacities, and the redox reaction kinetic parameters must be determined in order to design a suitable CLC reactor system $[3,4]$. Iron oxides have been extensively investigated worldwide due to their low cost, worldwide availability, the fact that they are more environmentally friendly in comparison with $\mathrm{Ni}$ - or $\mathrm{Cu}$-based oxygen carriers, and their favorable thermodynamic properties [13, 14]. The activity of $\mathrm{Fe}_{2} \mathrm{O}_{3}$ that was supported by $\mathrm{SiO}_{2}, \mathrm{Al}_{2} \mathrm{O}_{3}$, and $\mathrm{TiO}_{2}$ has been examined by different researchers [13, 17, 22]. However, the kinetic data for some of the oxygen carriers are still not fully available due to the different possible combinations of the chemical compositions of oxygen carriers. Son et al. [13] reported that the reduction reaction of a 60 mass $\% \mathrm{Fe}_{2} \mathrm{O}_{3}$ /bentonite material that was examined by TG (thermogravimetric analysis) within the temperature range of $700-1000{ }^{\circ} \mathrm{C}$ and with an application of $10 \mathrm{vol} \%$ $\mathrm{CH}_{4}$ followed the modified volumetric model. The determined $E_{\mathrm{a}}$ (activation energy) was equal to $29 \mathrm{~kJ} \mathrm{~mol}^{-1}$ for the reduction reaction, whereas the oxidation reaction followed the shrinking core model with an $E_{\mathrm{a}}$ equal to $6.0 \mathrm{~kJ} \mathrm{~mol}^{-1}$. Abad et al. [23] studied 60 mass $\% \mathrm{Fe}_{2} \mathrm{O}_{3} /$ $\mathrm{Al}_{2} \mathrm{O}_{3}$ with $\mathrm{TG}$ in the temperature range of $600-950{ }^{\circ} \mathrm{C}$ with $5-70$ vol\% $\mathrm{H}_{2}$ used as a reducer and $5 \mathrm{vol} \% \mathrm{O}_{2}$ used as an oxidizer. For the reduction reaction, the calculated $E_{\mathrm{a}}$ was $24 \mathrm{~kJ} \mathrm{~mol}^{-1}$, and for the oxidation reaction, $E_{\mathrm{a}}$ was calculated to be $14 \mathrm{~kJ} \mathrm{~mol}^{-1}$. For both reactions, the shrinking core model was accurate. Cabello et al. [24] presented results for the kinetic study of an impregnated $\mathrm{Fe}_{2} \mathrm{O}_{3} / \mathrm{Al}_{2} \mathrm{O}_{3}$ oxygen carrier with gaseous fuels such as $\mathrm{CH}_{4}, \mathrm{CO}$, and/or $\mathrm{H}_{2}$. The calculated reaction order values 
were $0.25,0.3$, and 0.6 for $\mathrm{CH}_{4}, \mathrm{H}_{2}$, and $\mathrm{CO}$, respectively. The calculated activation energy value was between $8 \mathrm{~kJ} \mathrm{~mol}^{-1}\left(\mathrm{H}_{2}\right)$ and $66 \mathrm{~kJ} \mathrm{~mol}^{-1}\left(\mathrm{CH}_{4}\right)$. They concluded that the kinetics of the oxidation reaction was only controlled by the chemical reaction mechanism with a reaction order of 0.9 and an $E_{\mathrm{a}}=23 \mathrm{~kJ} \mathrm{~mol}^{-1}$. For the reduction reaction, they also assumed that it was controlled by two different resistances. In other words, the reaction rate was controlled by the chemical reaction in the first step, whereas the mechanism that controlled the reactions at the higher conversion values was a diffusion through the product layer around the grains. Furthermore, they concluded that the reduction reaction mechanism was based upon the interactions of $\mathrm{Fe}_{2} \mathrm{O}_{3}$ with $\mathrm{Al}_{2} \mathrm{O}_{3}$ in the presence of the reacting gases that formed $\mathrm{FeAl}_{2} \mathrm{O}_{4}$.

The kinetic parameters of the redox reactions of Kryvbas ore with $\mathrm{CH}_{4}$ have not been reported in the literature. Based upon the previous results of the bimetallic carriers, it was concluded that the modeling of the reduction and oxidation reactions is specific to a given oxygen carrier and should be independently designated for each specific oxygen carrier [4]. Therefore, the objective of the present work is to study the kinetics of the reduction and oxidation reactions for the Kryvbas ore for use as a promising, lowcost, and naturally occurring oxygen carrier. The activation energy, pre-exponential factor, reaction order with respect to $\mathrm{CH}_{4}$ and $\mathrm{O}_{2}$, and reaction model were investigated. To simulate the methane/oxygen carrier reactions, the reactivity of the oxygen carriers was evaluated by conducting multi-cycle CLC tests by TG with methane being utilized as a fuel.

Coal is widely used in power plants for the generation of electricity in Poland. Methane is the one of the main components that is released during the pyrolysis of coal, which is one step of the heat treatment of coal. Due to the importance of the use of methane as one of the pyrolytic gas components because it is less reactive then $\mathrm{H}_{2}$ and $\mathrm{CO}$, it is important to investigate the performance of the oxygen carriers with regard to the methane conversion. If the oxygen carrier can quantitatively convert methane to $\mathrm{CO}_{2}$ and $\mathrm{H}_{2} \mathrm{O}$, it should be considered to be a promising material for use in future commercial applications.

\section{Experimental}

\section{Oxygen carrier preparation}

The oxygen carrier, Kryvbas ore, was obtained from the worldwide known steel producer ArcelorMittal S.A. Poland. Kryvbas ore, among other Fe oxide-based ores, is commonly used for the production of steel. Prior to the reactivity test and the study of the kinetics, the ore was subjected to a thermal treatment at $950{ }^{\circ} \mathrm{C}$ for $2 \mathrm{~h}$ in air. That procedure was necessary to remove any of the organic ingredients and possibly to improve the cyclic stability of CLC. The calcined sample was sieved, and the fraction of a $125-180 \mu \mathrm{m}$ was used for the measurements.

\section{Oxygen carrier characterization}

The elemental composition of the natural oxygen carrier was measured with atomic emission spectroscopy by ICPOES (Thermo ICAP 6500). A Micromeritics 3Flex instrument was used to determine the pore volume and surface area via $\mathrm{N}_{2}$ adsorption isotherms at $77 \mathrm{~K}$. Prior to the measurements, the samples were degassed under a vacuum at $350{ }^{\circ} \mathrm{C}$ for $4 \mathrm{~h}$. The surface area and pore size were calculated using the BET and Barrett-Joyner-Halenda methods, respectively. The crystal structures of the prepared samples were examined by $\mathrm{X}$-ray diffraction. Powder XRD patterns were recorded with a Siemens D500 $\mathrm{X}$-ray diffractometer with an auto-divergent slit and graphite monochromator using $\mathrm{CuK}_{\alpha}$ radiation at a scanning speed of $2^{\circ} \mathrm{min}^{-1}$. The characteristic reflection peaks ( $d$ values) were matched with JCPDS data files, and the crystalline phases were identified.

A scanning electron microscope (JEOL 6300) equipped with an X-ray EDS analyzer (Oxford Isis 2000) was used for the morphological observations of the samples. In order to be able to examine the morphologies and the compositions of the interior of the small particles of the Kryvbas ore (average size 125-185 $\mu \mathrm{m}$ ), the following method was utilized. Small quantities of sample were embedded in epoxy resin blocks that were initially kept at $40{ }^{\circ} \mathrm{C}$ under vacuum to prevent bubble formation and were then hardened for $24 \mathrm{~h}$. The hardened epoxy blocks were then ground and polished to expose the interiors of the particles (approximate cross sections) using silicon carbide paper to 1000 grid and diamond paste to $1 \mu \mathrm{m}$, respectively. Prior to data collection, the samples were cleaned in an ultrasonic bath in order to remove any embedded grid material. A thin gold film was deposited onto all of the samples by sputtering in order to make them conductive. Spot analysis and line scanning were the techniques utilized for the study. For the application of the line-scanning technique, a line was drawn that crosses the area of interest and the variations in the concentration of the component elements across this line were studied.

Stability of oxygen transport capacity was determined by TG. The experiments were conducted in a thermal analyzer (Netzsch STA 409 PG Luxx) coupled with a QMS (403C Aëolos). In the TG experiments, the mass change in the metal oxide OC was measured isothermally as a function of time. Ten reduction/oxidation cycles were 
conducted at atmospheric pressure to determine the reactivity of the oxygen carriers and their stability performance at $850-950{ }^{\circ} \mathrm{C}$. Approximately $100 \mathrm{mg}$ of sample was placed in an $\mathrm{Al}_{2} \mathrm{O}_{3}$ crucible. Three percentage $\mathrm{H}_{2}+$ steam/Ar was used for the reduction reaction, and $20 \% \mathrm{O}_{2} /$ $\mathrm{N}_{2}$ was used for the oxidation reaction, while the total reaction gas flow rates were set at $125 \mathrm{~mL} \mathrm{~min}^{-1}$. The reduction time was set at $45 \mathrm{~min}$ and the oxidation time at $30 \mathrm{~min}$. To avoid the mixing of reduction gases and air, the system was flushed with Ar for 15 min before and after each redox reaction.

\section{Study of the kinetics using a thermogravimetric analyzer}

Thermogravimetric analysis experiments were conducted in an HP $150 \mathrm{~s}$ TA pressurized thermogravimetric analyzer with a Rubotherm balance element coupled with a GSD-320 T3 Omnistar Pfeiffer Vacuum quadrupole mass spectrometer. In the TG experiments, the mass change in the oxygen carrier samples was measured isothermally as a function of the time during the reduction-oxidation cycles. Five reduction-oxidation cycles at each temperature and at atmospheric pressure were conducted for the determination of performance stability. A sample of approximately $100 \mathrm{mg}$ was heated in helium in a quartz crucible with fritted $\mathrm{Al}_{2} \mathrm{O}_{3}$ bottom to the reaction temperature. A $\mathrm{CH}_{4} / \mathrm{CO}_{2} / \mathrm{He}$ gas mixture was used for the reduction reaction in order to simulate the reaction of methane. Different methane concentrations were used. The range of the utilized fuel concentration was 10-25\%. Methane was chosen as a fuel because it is the main product of coal pyrolysis. Additionally, it has the lowest reactivity (slow kinetics) among all gaseous combustible gases. Therefore, it is significant to investigate the performance of the oxygen carriers with regard to the methane because it is less reactive than $\mathrm{H}_{2}$ and $\mathrm{CO}$. In other words, the reduction reaction of $\mathrm{OC}$ with $\mathrm{CH}_{4}$ will be the step limiting [23]. Sixty percentage of $\mathrm{CO}_{2}$ was added to the gas mixture in the reduction reaction. The reason for using $\mathrm{CO}_{2}$ was that carbon dioxide was an oxidation agent that helps maintain the reduction of hematite to only the magnetite phase by preventing a further reduction to wuestite or metallic $\mathrm{Fe}$ [24].

For the oxidation reactions, $5-20 \%$ of $\mathrm{O}_{2} / \mathrm{He}$ gas mixtures were used. The motivation for using different fuel and oxygen concentrations in the experiments is that it is required for the calculations of the reaction order with respect to gaseous fuel. To understand the effects of temperature, the TG experiments were performed at a range of temperatures from 750 to $950{ }^{\circ} \mathrm{C}$. Moreover, by applying different temperatures at fixed fuel/He and $\mathrm{O}_{2} / \mathrm{He}$ concentrations, the activation energy and pre-exponential factor calculations were able to be performed. In all of the experiments, the total reaction gas flow rates were $1000 \mathrm{~mL} \mathrm{~min}^{-1}$, the reduction time was between $60-180 \mathrm{~min}$, and the oxidation reaction time was 30-40 min depending upon the temperature conditions. To avoid the mixing of the reduction gases and air, the system was flushed with helium for 15-60 min before and after each reduction reaction. Moreover, the TG reaction parameters were set experimentally to assure being in kinetic region (mass of the sample, flow rates). The matrix of that describing the experiments for the evaluation of the redox reactions kinetics for the oxygen carriers is shown in Table 1 .

\section{Kinetic analysis}

Fractional conversions, i.e., the fractional reduction conversions and the fractional oxidation conversions, were calculated utilizing the TG data of the fifth redox cycle. The fractional conversion $(X)$ is defined as follows [4]:

Fractional reduction: $X=\frac{M_{\text {oxd }}-M}{M_{\text {oxd }}-M_{\text {red }}}$

Fractional oxidation: $X=\frac{M-M_{\mathrm{red}}}{M_{\mathrm{oxd}}-M_{\mathrm{red}}}$

where $M$ is the instantaneous mass, $M_{\text {oxd }}$ is the mass of a completely oxidized sample in TG (maximum mass after

Table 1 Matrix of experiments for evaluation of redox reaction kinetics for oxygen carriers

\begin{tabular}{|c|c|c|c|c|}
\hline $\begin{array}{l}\text { Reduction } \\
\text { Oxidation }\end{array}$ & $\begin{array}{l}10 \% \mathrm{CH}_{4} / 60 \% \\
\mathrm{CO}_{2} / 30 \% \mathrm{He} \\
10 \% \mathrm{O}_{2} / \mathrm{He}\end{array}$ & $\begin{array}{l}15 \% \mathrm{CH}_{4} / 60 \% \\
\mathrm{CO}_{2} / 25 \% \mathrm{He} \\
5 \% \mathrm{O}_{2} / \mathrm{He}\end{array}$ & $\begin{array}{l}20 \% \mathrm{CH}_{4} / 60 \% \\
\mathrm{CO}_{2} / 20 \% \mathrm{He} \\
20 \% \mathrm{O}_{2} / \mathrm{He}\end{array}$ & $\begin{array}{l}25 \% \mathrm{CH}_{4} / 60 \% \\
\mathrm{CO}_{2} / 15 \% \mathrm{He} \\
15 \% \mathrm{O}_{2} / \mathrm{He}\end{array}$ \\
\hline \multicolumn{5}{|c|}{ Temperature $/{ }^{\circ} \mathrm{C}$} \\
\hline 750 & & & + & \\
\hline 800 & & & + & \\
\hline 850 & & & + & \\
\hline 900 & + & + & + & + \\
\hline 950 & & & + & \\
\hline
\end{tabular}


Table 2 Tested reaction models

\begin{tabular}{llr}
\hline Model & $f(X)=$ & $g(X)=$ \\
\hline Volumetric model (F1) & $1-X$ & $-\ln (1-X)$ \\
Shrinking core model (R3) & $3(1-X)^{2 / 3}$ & $1-(1-X)^{1 / 3}$ \\
Three-dimensional diffusion model (D3) & $\frac{3}{2}(1-X)^{2 / 3}\left(1-(1-X)^{1 / 3}\right)$ & $\left(1-(1-X)^{1 / 3}\right)^{2}$ \\
\hline
\end{tabular}

oxidation with air), and $M_{\text {red }}$ is the mass of a completely reduced sample in TG (minimum mass after reduction with methane). In this study, $M_{\text {red }}$ is considered as the mass of $\mathrm{Fe}_{3} \mathrm{O}_{4}$, and $100 \%$ conversion means that the $\mathrm{Fe}_{2} \mathrm{O}_{3}$ (hematite) was completely converted to $\mathrm{Fe}_{3} \mathrm{O}_{4}$ (magnetite).

Because the calculations described in this paper do account for the concentration of the gaseous substrate, a kinetic expression for the solid-gas reaction rate can be described by the following Eq. (3):

$\frac{\mathrm{d} X}{\mathrm{~d} t}=k^{\prime} P^{\mathrm{n}} f(X)$

where $f(X)$ is a structural factor or a model of the reaction that describes the physical or chemical properties during the reaction, $P$ is the partial pressure of methane or oxygen, for the reduction and oxidation reactions, respectively, $n$ is the reaction order with respect to the gaseous reactant, and $k^{\prime}$ is the reaction rate constant that can be described by the Arrhenius Eq. (4):

$k^{\prime}=A_{0} \mathrm{e}^{\frac{-\mathrm{Ea}}{\mathrm{RT}}}$

where $A_{0}$ is the pre-exponential factor, $E_{\mathrm{a}}$ is the activation energy, and $R$ is the gas constant that is equal to $8.314 \mathrm{~J} \mathrm{~mol} \mathrm{~K}^{-1}$.

In this paper, three models (Table 2) were chosen to determine the model that best fit the experimental data and that could describe the reaction in a proper manner. Among them were the volumetric model, the shrinking core model, and the three-dimensional diffusion model (Jander's type). Table 2 presents the models of these reaction as $f(X)$ and $g(X)$ functions. These three models were applied to the reactions occurring in the $\mathrm{TG}$ system during the cycling experiments, i.e., the reduction by $\mathrm{CH}_{4}$ and the oxidation by $\mathrm{O}_{2}$ from the synthetic air. The first step of calculations was the fitting of the model with the raw TG data. For this purpose, Eq. (7) was transformed to Eq. (5): $\frac{\mathrm{d} X}{f(X)}=k \mathrm{~d} t$

where

$k=k^{\prime} \cdot P^{\mathrm{n}}$

where $k$ is the kinetic constant that relates the partial pressure of the reactant to the reaction order power.

After integration, Eq. (2) can be described by the expression of the $g(X) \mathrm{Eq}$. (7):

$g(X)=\int \frac{\mathrm{d} X}{f(X)}$

The volumetric model assumes that the reaction occurs throughout the particles of the oxygen carrier and that the mass of the oxygen carrier grain changes linearly during the reaction. The shrinking core model assumes that the reaction occurs on the external surface of the grain, which changes during the reaction. The three-dimensional diffusion model describes a reaction in which the diffusion of oxygen from the unreacted metal oxide through the metal layer to the surface of the particle is the reaction-limiting step.

One method of fitting the model to the experimental data is determining the linearity of the $g(X)$ function versus time. The slope of this function results in the reaction rate constant $k^{\prime}$. For the calculation of the other kinetic parameters, such as $E_{\mathrm{a}}$ and $A_{0}$, the reaction rate constant must be calculated for the different temperatures. Then, the activation energy and the pre-exponential factors are calculated from the Arrhenius equation as the slope and intercept of $\ln (k)$ versus $1 / T$, respectively, based on Eq. (8):

$\ln (k)=-\frac{E_{\mathrm{a}}}{R} \cdot \frac{1}{T}+\ln \left(A_{0} \cdot P^{\mathrm{n}}\right)$

The reaction order with respect to $\mathrm{CH}_{4}$ (fuel, reducer), the gaseous reagent that is in this paper and

Table 3 Chemical composition, phase composition, and BET surface area

\begin{tabular}{llllllllllll}
\hline Chemical composition/\% & \multicolumn{1}{l}{1} & & & & Phase composition & Surface area/m $^{2} \mathrm{~g}^{-1}$ \\
\hline $\mathrm{Fe}_{2} \mathrm{O}_{3}$ & $\mathrm{SiO}_{2}$ & $\mathrm{Al}_{2} \mathrm{O}_{3}$ & $\mathrm{CaO}$ & $\mathrm{P}_{2} \mathrm{O}_{5}$ & $\mathrm{MgO}$ & $\mathrm{SO}_{3}$ & $\mathrm{TiO}_{2}$ & $\mathrm{Mn}_{3} \mathrm{O}_{4}$ & $\mathrm{Fe}_{2} \mathrm{O}_{3}, \mathrm{SiO}_{2}$ & 0.63 \\
84.86 & 8.55 & 1.03 & 0.29 & 0.12 & 0.11 & 0.04 & 0.03 & 0.02 & & & \\
\hline
\end{tabular}


Fig. 1 X-ray diffraction patterns of Kryvbas ore a calcined in air at $950{ }^{\circ} \mathrm{C}$ and b after five redox cycles at $950{ }^{\circ} \mathrm{C}$, with $25 \% \mathrm{CH}_{4} / 60 \%$ $\mathrm{CO}_{2} / 15 \% \mathrm{He}$ as "fuel mixture" and $15 \% \mathrm{O}_{2} / \mathrm{He}$ as "oxidation mixture"

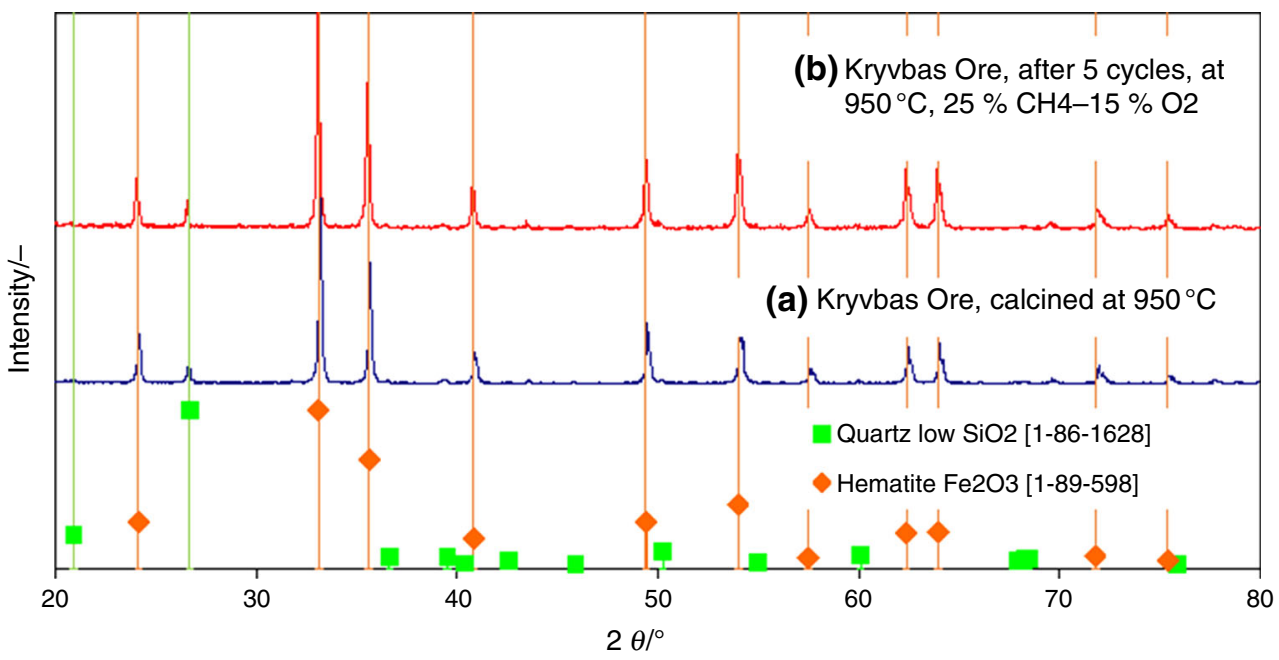

Alka,42
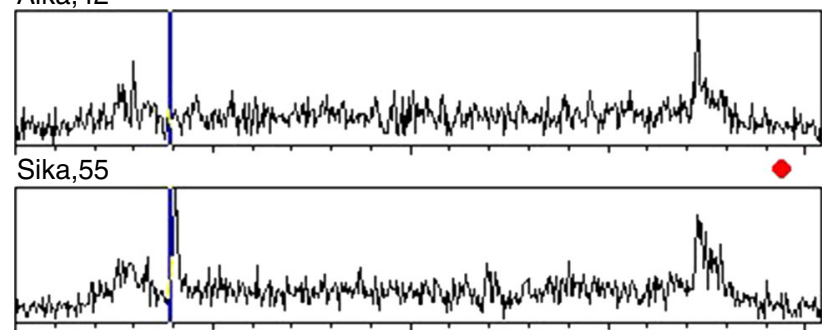

Feka,229
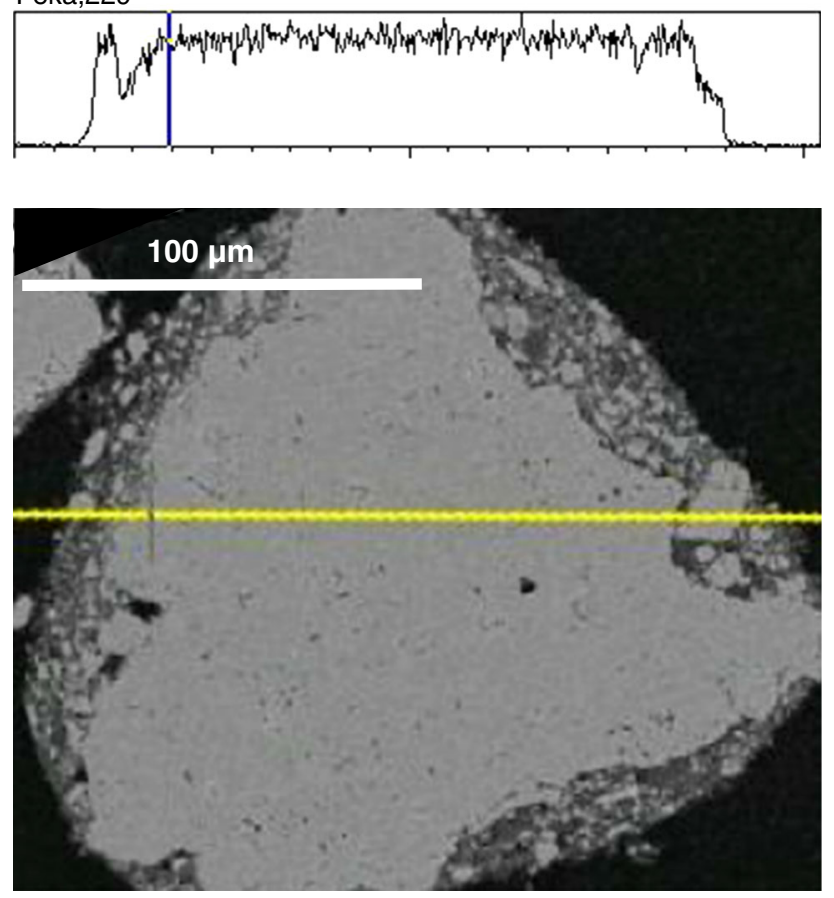

Fig. 2 Elemental concentration of $\mathrm{Al}, \mathrm{Si}$, and $\mathrm{Fe}$ across a particle (along the yellow line) of Kryvbas oxygen carrier, calcined in air at $950{ }^{\circ} \mathrm{C}$ (magnification $\times 500$ )

$\mathrm{O}_{2}$ (oxidizer) was calculated based on Eq. (6) and its logarithmic form (9):

$\ln (k)=\ln \left(k^{\prime}\right)+n \cdot \ln P_{\mathrm{g}}$
This means that the reaction order with respect to the gaseous reactant can be determined from Eq. (8) by the slope and intercept of $\ln (k)$ versus $\ln (P)$ (Eq. 9) at a fixed temperature (as shown in Table 1, at $900{ }^{\circ} \mathrm{C}$ temperature).

\section{Results and discussion}

\section{Oxygen carrier characterization}

The Kryvbas ore sample was studied, in terms of its chemical composition, by ICP-OES, and the analysis revealed that the Fe-based oxide material was mostly composed of $\mathrm{Fe}_{2} \mathrm{O}_{3}$ (84.86 mass\%), $\mathrm{SiO}_{2}$ (8.55 mass\%), and $\mathrm{Al}_{2} \mathrm{O}_{3}(1.03$ mass\%), as well as traces of other elements, as shown in Table 3.

Further analysis of the calcined samples of the Kryvbas ore showed a small surface area, $0.63 \mathrm{~m}^{2} \mathrm{~g}^{-1}$, as presented in Table 3, while for the fresh Kryvbas ore, the BET test resulted in a surface area of $1.49 \mathrm{~m}^{2} \mathrm{~g}^{-1}$. This behavior indicated that the oxidation pretreatment caused a decrease in the surface area. Because the surface area is small, it is possible that the performance of this oxygen carrier should not only be attributed to the surface area. The pore size shares were calculated for the fresh sample with the following results: $5.36 \%$ micropores, $52.01 \%$ mesopores, and $42.63 \%$ macropores; share results for the calcined sample were determined as follows: $5.49 \%$ micropores, $40.33 \%$ mesopores, and $54.19 \%$ macropores. This means that the calcination caused an increase in the percentage of the macropores at the expense of the mesopores.

The XRD pattern of the Kryvbas ore sample calcined at $950{ }^{\circ} \mathrm{C}$ is shown in Fig. 1a together with its phase identification. From the figure, it can be revealed that the 


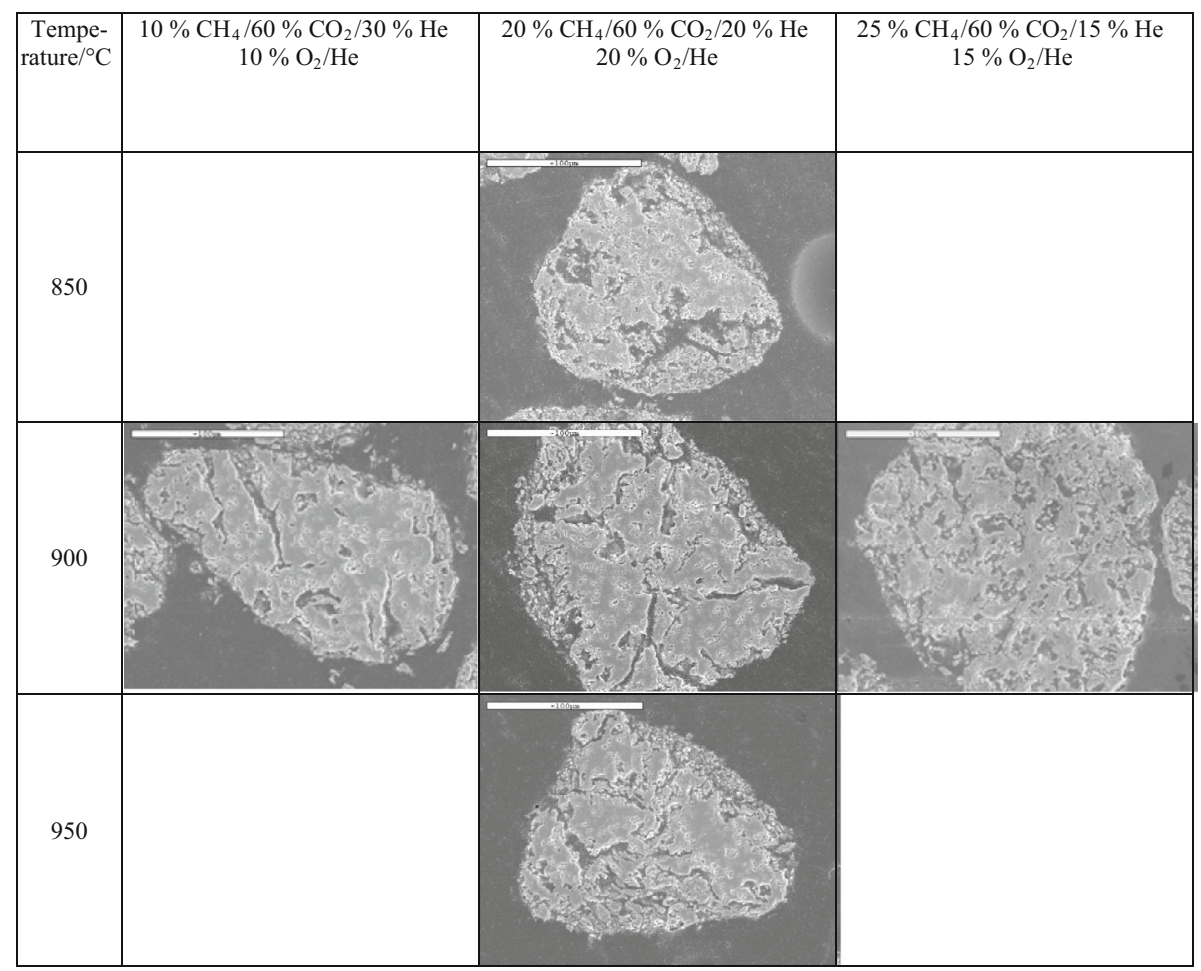

Fig. 3 SEM images of selected particles of Kryvbas ore after five redox cycles at the conditions denoted in the table

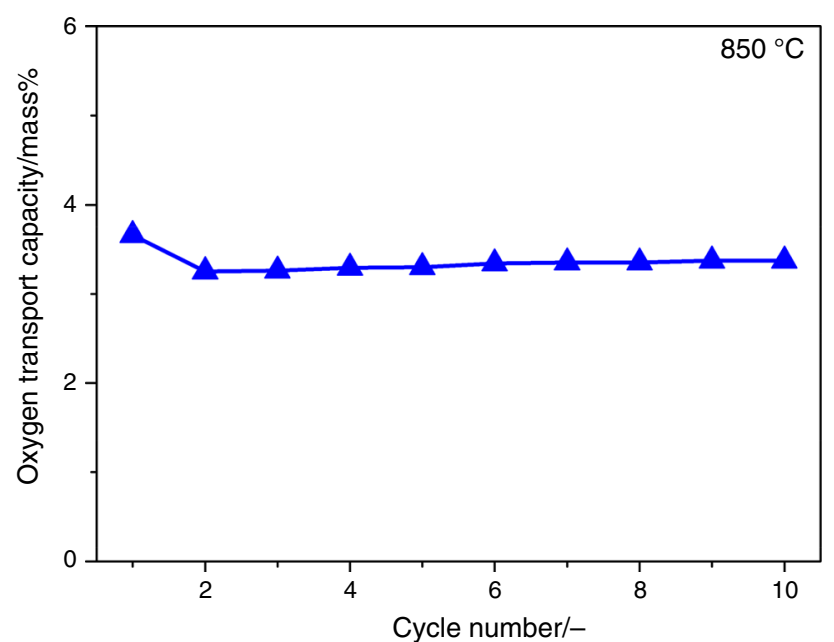

Fig. 4 10-cycle reduction/oxidation TG data for the Kryvbas ore oxygen carrier at $850{ }^{\circ} \mathrm{C}$ with $3 \% \mathrm{H}_{2}+$ steam/Ar

dominating phases of the calcined ore were hematite and inert silicon oxide, which is in agreement with the elemental analysis (Table 3) that showed that Fe and, to a lesser extent $\mathrm{Si}$, were the main components of the ore. In the same figure, the XRD pattern of the "reacted" ore is presented (Fig. 1b) after five redox cycles at $950{ }^{\circ} \mathrm{C}$ with $25 \% \mathrm{CH}_{4} / 60 \% \mathrm{CO}_{2} / 15 \% \mathrm{He}$ as the "fuel mixture" and
Table 4 Oxygen transfer capacity of the oxygen carriers under different reduction states

\begin{tabular}{lll}
\hline Oxygen carrier & Reactions & $\begin{array}{l}\text { Theoretical } \\
\text { oxygen transfer } \\
\text { capacity/mass\% }\end{array}$ \\
\hline $84.86 \%$ & $3 \mathrm{Fe}_{2} \mathrm{O}_{3} \leftrightarrow 2 \mathrm{Fe}_{3} \mathrm{O}_{4}+1 / 2 \mathrm{O}_{2}$ & 2.83 \\
$\mathrm{Fe}_{2} \mathrm{O}_{3}$ /support & & \\
& $\mathrm{Fe}_{2} \mathrm{O}_{3} \leftrightarrow 2 \mathrm{FeO}+1 / 2 \mathrm{O}_{2}$ & 8.50 \\
& $\mathrm{Fe}_{2} \mathrm{O}_{3} \leftrightarrow 2 \mathrm{Fe}+3 / 2 \mathrm{O}_{2}$ & 25.51 \\
\hline
\end{tabular}

$15 \% \mathrm{O}_{2} / \mathrm{He}$ as the "oxidation mixture." The reaction conditions of the "reacted" sample of Fig. 1b are the most severe among those used in the present study. Comparison of the XRD patterns of the fresh and the "reacted" sample indicated that Kryvbas ore retained its structure, it did not decompose, and no new phases were formed after being exposed to the redox reactions even at the highest temperature that was tested. The lack of the phase changes is not only due to the number of cycles performed. The most probable reason for that is that the iron silicate formation was prevented. Based on thermodynamic simulation with application of HSC Chemistry v. 7.0 software, it was proved that silicates are not stable within the used reaction conditions. Moreover, since reduction of $\mathrm{Fe}_{2} \mathrm{O}_{3}$ (hematite) was processed to $\mathrm{Fe}_{3} \mathrm{O}_{4}$ (magnetite), $\mathrm{FeO}$ (wuestite) 

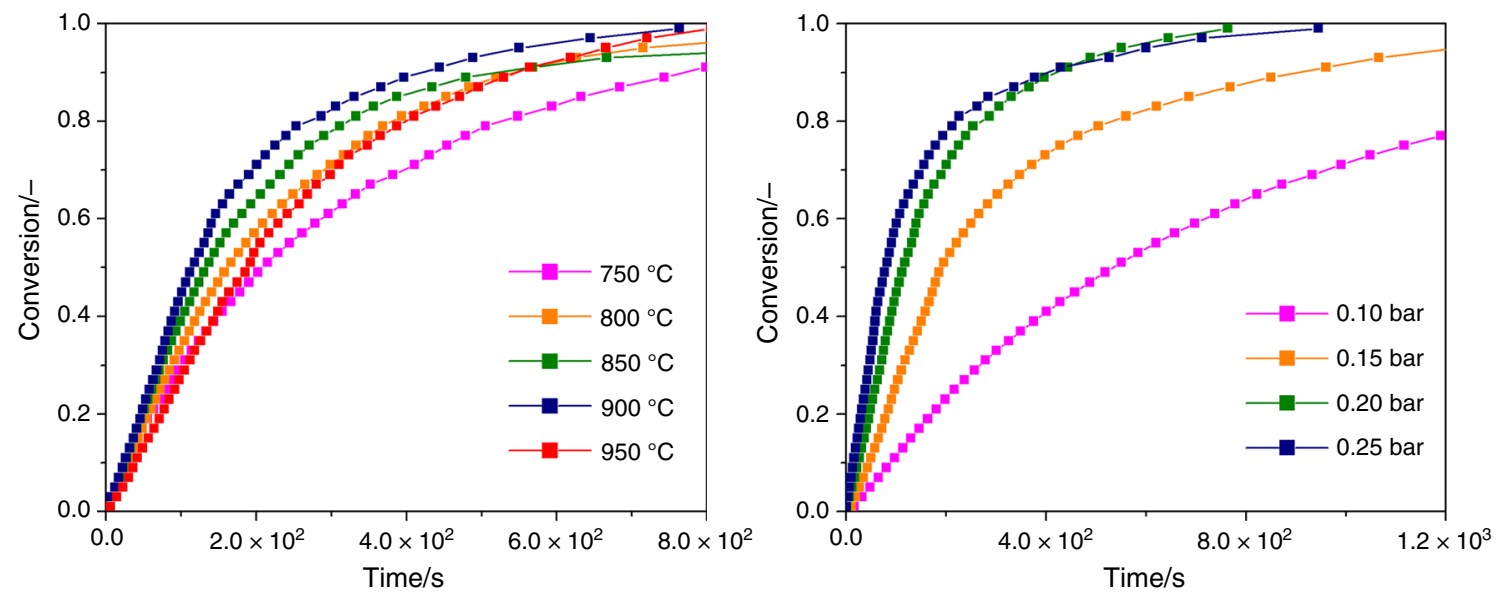

Fig. 5 Fractional reduction versus time for Kryvbas ore for different temperature conditions and different regent $\left(\mathrm{CH}_{4}\right)$ concentration conditions

Table 5 Reduction reaction kinetics study for Kryvbas ore

\begin{tabular}{|c|c|c|c|c|c|c|}
\hline \multirow[t]{2}{*}{$\mathrm{T} /{ }^{\circ} \mathrm{C}$} & \multicolumn{2}{|l|}{ Model F1 } & \multicolumn{2}{|l|}{ Model R3 } & \multicolumn{2}{|l|}{ Model D3 } \\
\hline & $\mathrm{k} / \mathrm{s}^{-1}$ & $R^{2}$ & $\mathrm{k} / \mathrm{s}^{-1}$ & $R^{2}$ & $\mathrm{k} / \mathrm{s}^{-1}$ & $R^{2}$ \\
\hline 750 & $3.069 \times 10^{-3}$ & 0.996 & $8.040 \times 10^{-4}$ & 0.965 & $3.078 \times 10^{-4}$ & 0.923 \\
\hline 800 & $4.202 \times 10^{-3}$ & 0.999 & $1.105 \times 10^{-3}$ & 0.983 & $4.173 \times 10^{-4}$ & 0.873 \\
\hline 850 & $4.914 \times 10^{-3}$ & 0.995 & $1.288 \times 10^{-3}$ & 0.965 & $4.912 \times 10^{-4}$ & 0.902 \\
\hline 900 & $5.856 \times 10^{-3}$ & 0.992 & $1.536 \times 10^{-3}$ & 0.965 & $5.838 \times 10^{-4}$ & 0.884 \\
\hline
\end{tabular}

formation was not completed. Therefore, those reaction conditions prevented iron silicates formation and maintained the crystal structure of OC. The XRD patterns of the samples after the redox cycles at lower temperatures (not shown here) also demonstrated, as expected, the stability of the crystalline structure.

Figure 2 shows a linescan of a typical particle from the calcined ore at $950{ }^{\circ} \mathrm{C}$. The content distribution for the most important elements, $\mathrm{Fe}, \mathrm{Si}$, and $\mathrm{Al}$, is presented along the yellow line indicated in the particle image at the lower part of the figure. Variations in the concentration of $\mathrm{Fe}, \mathrm{Si}$, and $\mathrm{Al}$ indicated the presence of different components of the ore along the line: a solid hematite $\left(\mathrm{Fe}_{2} \mathrm{O}_{3}\right)$ core that was surrounded by a mixed phase composed of small particles $(2-10 \mu \mathrm{m})$ of $\mathrm{SiO}_{2}, \mathrm{Al}_{2} \mathrm{O}_{3}$, and $\mathrm{Fe}_{2} \mathrm{O}_{3}$.

Figure 3 shows typical SEM images of the ore particles after five redox cycles at the conditions described in Table 1. By comparing the morphological characteristics of the particles shown in Fig. 3 to those of the calcined particle of Fig. 2, it can be concluded that the repetitive reduction-oxidation reactions did not affect the crystalline structure of the material, although they did cause extensive wearing away to the particles which can lead to a reduced mechanical stability of the material. The extent of the destruction was in direct comparison with the severity of the redox reaction conditions.
An example of the 10-cycle reduction/oxidation TG data for the Kryvbas ore oxygen carrier at $850{ }^{\circ} \mathrm{C}$ with $3 \% \mathrm{H}_{2} /$ $\mathrm{Ar}+$ steam as a function of reactivity pretesting is shown in Fig. 4.

The continuous, constant chemical-looping combustion performance was observed within the framework of the 10-cycle test. The same excellent behavior was also observed for other temperatures in the range of $750-950{ }^{\circ} \mathrm{C}$. Based on the pretesting in the severe reduction conditions with hydrogen, the 5-cycle test for the kinetic study with methane was completed. It is important to note that the use of the Kryvbas ore as a potential oxygen carrier sample did not require an extra treatment, such as an activation that is required in the case of ilmenite, which is another natural carrier $[16,17]$.

The stable TG data from the fifth redox cycle were used in the calculations. Mathcad Prime 2.0 software was used in the determination of the kinetic parameters. The complete redox cycle was composed of the reduction reaction, a flush with helium, and a regeneration reaction of the oxygen carrier. Due to the reduction reaction of the oxygen carrier, a decrease in the mass was observed because the reducing agent, $\mathrm{CH}_{4}$, was introduced into the TG chamber. Afterward, the system was flushed with inert helium to remove the combustion gases from the TG chamber. After the flush, the oxidation reaction 

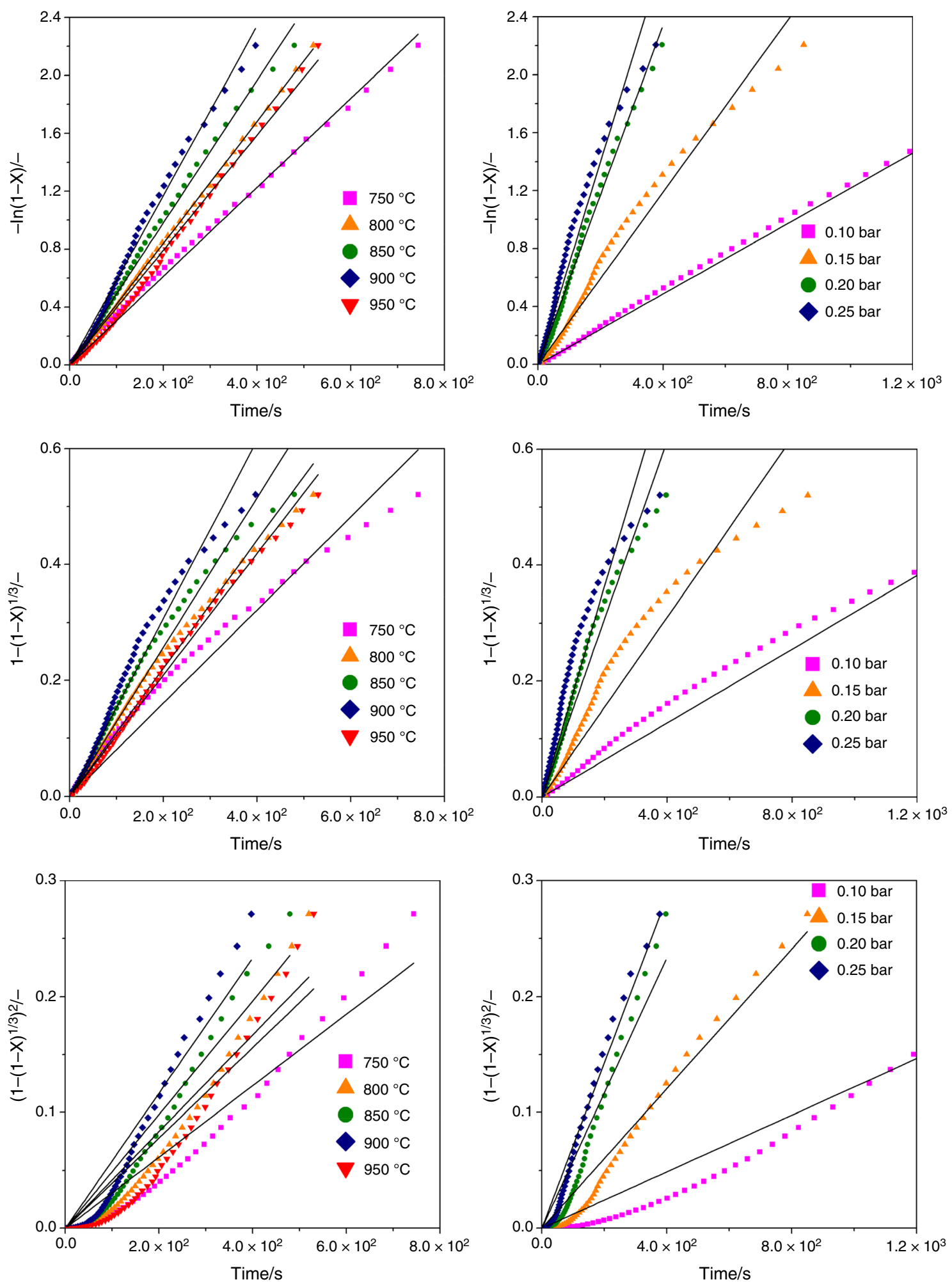

Fig. 6 Model fitting for the reduction reaction of Kryvbas ore for different temperatures and $\mathrm{CH}_{4}$ partial pressure

occurred, regenerating the reduced oxygen carrier, and a corresponding increase in mass was observed on the TG graph.
Because one of the most important applied parameters for the selection of an oxygen carrier for a CLC power plant is the oxygen transport capacity, the oxygen transport 
capacities were calculated for an Fe-based, naturally occurring oxygen carrier of 84.86 mass $\% \quad \mathrm{Fe}_{2} \mathrm{O}_{3}$, 8.55 mass $\% \mathrm{SiO}_{2}$, and 1.03 mass $\% \mathrm{Al}_{2} \mathrm{O}_{3}$. The theoretical mass changes in accordance with the reaction stoichiometry for the $\mathrm{CH}_{4}$ gas reduction of $\mathrm{Fe}_{2} \mathrm{O}_{3}$ were calculated according to the reactions:

$$
\begin{aligned}
& 12 \mathrm{Fe}_{2} \mathrm{O}_{3}+\mathrm{CH}_{4} \rightarrow 8 \mathrm{Fe}_{3} \mathrm{O}_{4}+\mathrm{CO}_{2}+2 \mathrm{H}_{2} \mathrm{O} \\
& 4 \mathrm{Fe}_{2} \mathrm{O}_{3}+\mathrm{CH}_{4} \rightarrow 8 \mathrm{FeO}+\mathrm{CO}_{2}+2 \mathrm{H}_{2} \mathrm{O} \\
& 4 \mathrm{Fe}_{2} \mathrm{O}_{3}+3 \mathrm{CH}_{4} \rightarrow 8 \mathrm{Fe}+3 \mathrm{CO}_{2}+6 \mathrm{H}_{2} \mathrm{O}
\end{aligned}
$$

The theoretical oxygen transfer capacity (mass \%) depends upon the material that comprises the oxygen carrier and the final reduction state. The oxygen transfer capacities of the oxygen carriers at the different reduction states are listed in Table 4. Based on the reactions (Eqs. 10, 11), it was determined that the theoretical mass decrease that corresponded to a reduction of $\mathrm{Fe}_{2} \mathrm{O}_{3}$ to $\mathrm{Fe}_{3} \mathrm{O}_{4}$ in the Kryvbas ore sample (where the amount of active phase that is $\mathrm{Fe}_{2} \mathrm{O}_{3}$ is equal to 84.86 mass\%) was 2.83 mass\%. The reduction of $\mathrm{Fe}_{2} \mathrm{O}_{3}$ to $\mathrm{FeO}$ or to $\mathrm{Fe}$ corresponded to a percent mass decrease of 8.50 and 25.51, respectively. In the TG experiments, overall oxygen transport capacities of approximately 2.8 mass $\%$ were achieved. That is similar as for other natural Fe-based OC (ilmenite) [16].

This capacity was completed by the application of $\mathrm{CO}_{2}$ stream that was added to fuel. Based upon the observed mass decreases in the experiments, it can be concluded that the final reduction state for the sample was $\mathrm{Fe}_{3} \mathrm{O}_{4}$. That observations were also supported by the data obtained within thermodynamic calculations made in FactSage program (The Integrated Thermodynamic Databank System). With FactSage calculation of the TG conditions for multiphase and multicomponent equilibria, under different constraints, that is addition of $\mathrm{CO}_{2}$ to $\mathrm{CH}_{4}$ and pure $\mathrm{CH}_{4}$, the phase was validated. Therefore, the kinetics data describe the final reduction of $\mathrm{Fe}_{2} \mathrm{O}_{3}$ to $\mathrm{Fe}_{3} \mathrm{O}_{4}$.

The fractional conversions for the reduction and oxidation reactions were calculated based upon Eqs. (1) and (2). Figure 5 shows the fractional reduction for the highly concentrated $\mathrm{Fe}$ natural oxygen carrier that was calculated at a temperature range of $750-950{ }^{\circ} \mathrm{C}$. The temperature had on a positive effect on the reaction rate, and this was evidenced by the observation that when the temperature increased, the reaction rate also increased. Figure 5 also shows the fractional reduction versus time for the Kryvbas ore for different methane concentrations $(10,15,20$, and $25 \%)$. Here, an increase in the reduction rate was also observed with a corresponding increase in the reagent concentration.

In the literature, both the shrinking core and diffusion model were the most frequently indicated for the description of the Fe oxide reduction reaction [14-17, 24], which was the motivation of using both of these mentioned models in the natural oxygen carrier (Fe-based) kinetics calculations. In addition to these models, another model (e.g., the volumetric model) was also tested. The results for the volumetric model (marked by F1), the shrinking core model (marked by R3), and the three-dimensional diffusion model (marked by D3) are shown in Table 5 .

For all of the models, the $k$-kinetic constant and the correlation coefficient were calculated. Figure 6 shows the fitting of these three models for the reduction reactions at all of the temperatures and $\mathrm{CH}_{4}$ concentrations. The plots of the function $\mathrm{g}(X)$ versus time for the reduction of the Kryvbas ore for these three models according to the equations from Table 2 were also shown. Based upon the calculated data, it may be concluded that both the R3 and the F1 models fit well and they described the behavior of the oxygen carrier during the reaction.

Considering the $R^{2}$ values given in Table 5 throughout the entire temperature range, the F1 model possessed the best correlation. The calculated reduction reaction parameters for the F1 model were $E_{\mathrm{a}}=42.00 \mathrm{~kJ} \mathrm{~mol}^{-1}$, $R^{2}=0.982$, and $A_{0}=9.8810^{-6} \mathrm{~s}^{-1} \mathrm{~Pa}^{\mathrm{n}}$, and these values are shown in the Arrhenius plot of the reduction reaction in Fig. 7. The data from the reaction at $950{ }^{\circ} \mathrm{C}$ were not included in the calculation of $E_{\mathrm{a}}$ because of its lower reaction rate. This reduction in reaction rate was most likely caused by a sintering of the sample during the redox cycles. The $E_{\mathrm{a}}$ value of the reduction reaction is a little bit higher compared with the $E_{\mathrm{a}}$ for other Fe-based oxygen carriers that have been reported in the literature, which

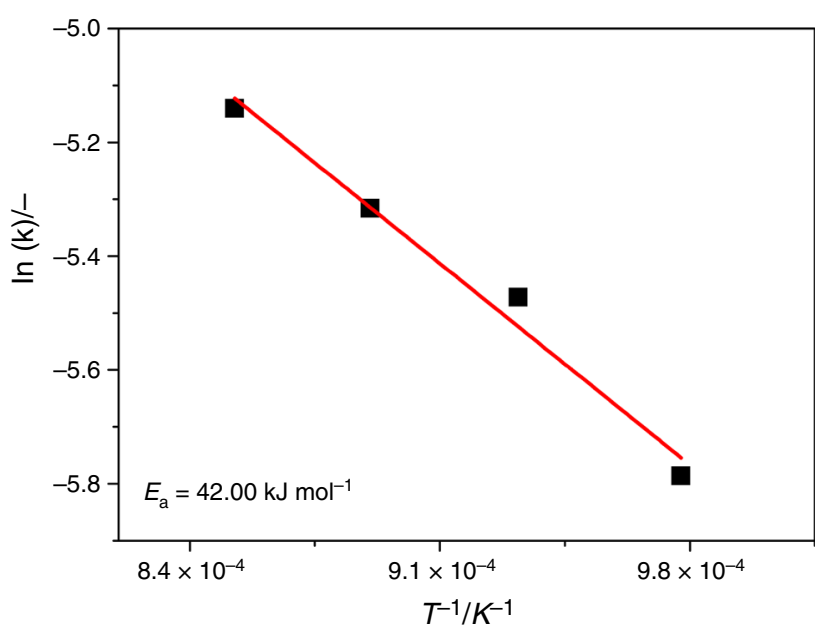

Fig. 7 Arrhenius plot of the reduction reaction of Kryvbas ore for applied model F1 


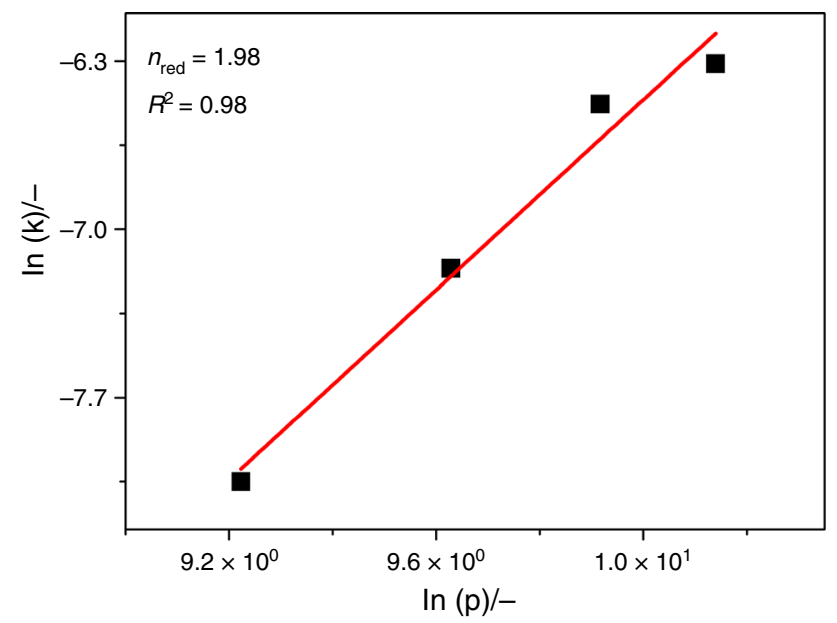

Fig. 8 Reduction reaction order determination

were reported as $33.8 \mathrm{~kJ} \mathrm{~mol}^{-1}$ for $\mathrm{Fe}_{2} \mathrm{O}_{3} / \mathrm{TiO}_{2}$ [4] and $29 \mathrm{~kJ} \mathrm{~mol}^{-1}$ for $\mathrm{Fe}_{2} \mathrm{O}_{3}$ /bentonite [13].

The determined reduction reaction order for model F1 was equal to 1.98 and that is shown in Fig. 8. This value of reaction order suggests a more complex mechanism was involved in the reduction of the Kryvbas ore. According to the calculations, the reduction reaction proceeded uniformly throughout the whole grain and that there was no diffusion limitation.

Figure 9 shows the oxidation conversion of $\mathrm{Fe}_{3} \mathrm{O}_{4}$ to $\mathrm{Fe}_{2} \mathrm{O}_{3}$ versus time for the Kryvbas ore under different reaction conditions. The presented curves show the fractional oxidation (regeneration) conversion for the different tested temperatures and also the different concentrations of $\mathrm{O}_{2}$. For the model fitting calculations, the range of the data that was taken into account was narrowed to approximately $60 \mathrm{~s}$, which corresponded to a conversion degree of $0.7-0.9$. The oxidation reaction was significantly faster than the reduction reaction. It was also observed that for tested temperature range of $750-950{ }^{\circ} \mathrm{C}$, the temperature possessed a positive effect on the oxidation reaction rate.

As it can be seen from Fig. 9, an increase in the $\mathrm{O}_{2}$ concentration led to a corresponding increase in the oxidation reaction rates. That indicates that both temperature and the $\mathrm{O}_{2}$ concentration have a positive effect on the oxidation rates of the Kryvbas ore.

In Fig. 10, the plots of the function $g(X)$ versus time for the temperature range between $750-950{ }^{\circ} \mathrm{C}$ and at different partial pressures of $\mathrm{O}_{2}$ are presented. Table 6 shows the reaction rate constants and the correlation coefficients for the three models that were studied. The most suitable model for the description of the sample behavior when it was oxidized by air in the given temperature range, as indicated by the data collected, was the R3 model. The F1 and D3 models both possessed a poor fit to the data (Table 6; Fig. 10).

Based upon the correlation factors, the R3 model was the most suitable model for the description of the oxidation reaction. Therefore, the activation energy was determined for the model, and the plot of the logarithm of the reaction rate constant versus the inverse temperature (Arrhenius plot) is shown in Fig. 11. The calculated activation energy for the oxidation reaction was equal to $16.70 \mathrm{~kJ} \mathrm{~mol}^{-1}$, and the pre-exponential factor was equal to $1.53 \mathrm{~s}^{-1} \mathrm{~Pa}^{\mathrm{n}}$. The oxidation reaction order, shown in Fig. 12, was determined and was estimated to be 0.49 . The data presented by Son et al. [13] for the 60 mass $\%$ $\mathrm{Fe}_{2} \mathrm{O}_{3}$ /bentonite showed that the activation energy of the oxidation reaction was lower and equal to $6 \mathrm{~kJ} \mathrm{~mol}^{-1}$. During the oxidation reaction, which was faster than the reduction reaction, an $\mathrm{Fe}_{2} \mathrm{O}_{3}$ product layer can be formed around the unreacted core of $\mathrm{Fe}_{3} \mathrm{O}_{4}$, and a resistance to the diffusion of $\mathrm{O}^{2-}$ or $\mathrm{Fe}^{3+}$ ions may play an important role.
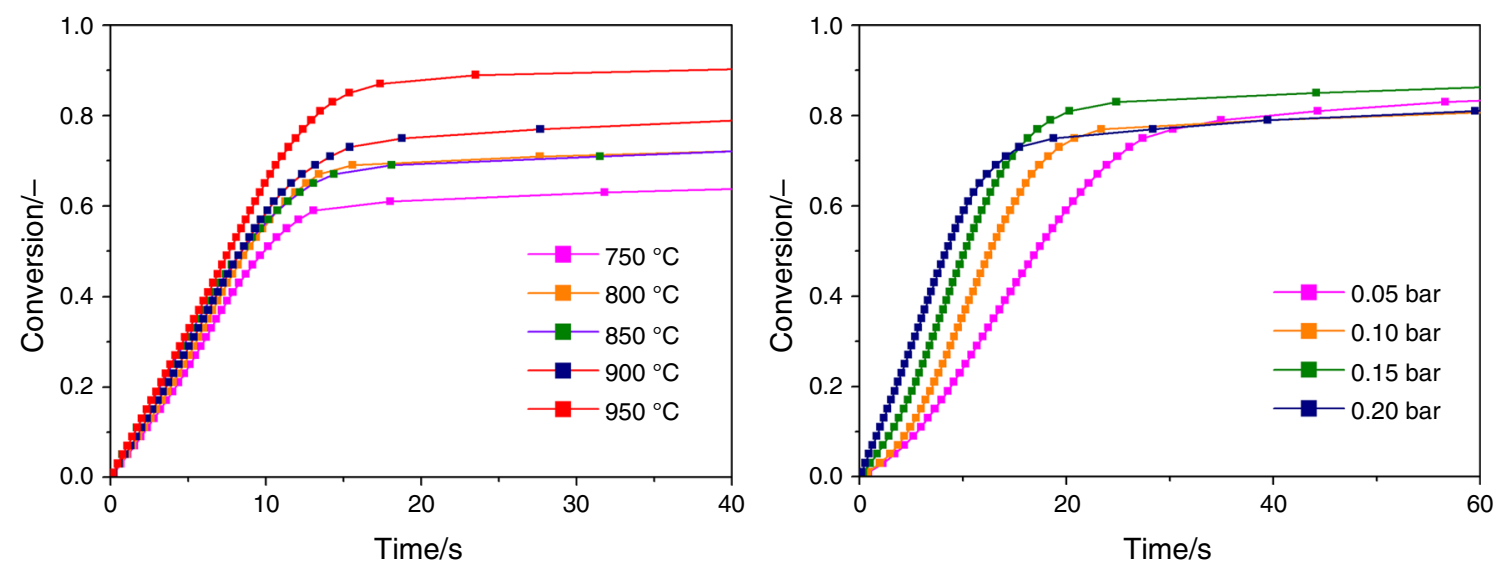

Fig. 9 Oxidation degree versus time of Kryvbas ore for both different temperatures and different regent $\left(\mathrm{O}_{2}\right)$ concentration conditions 

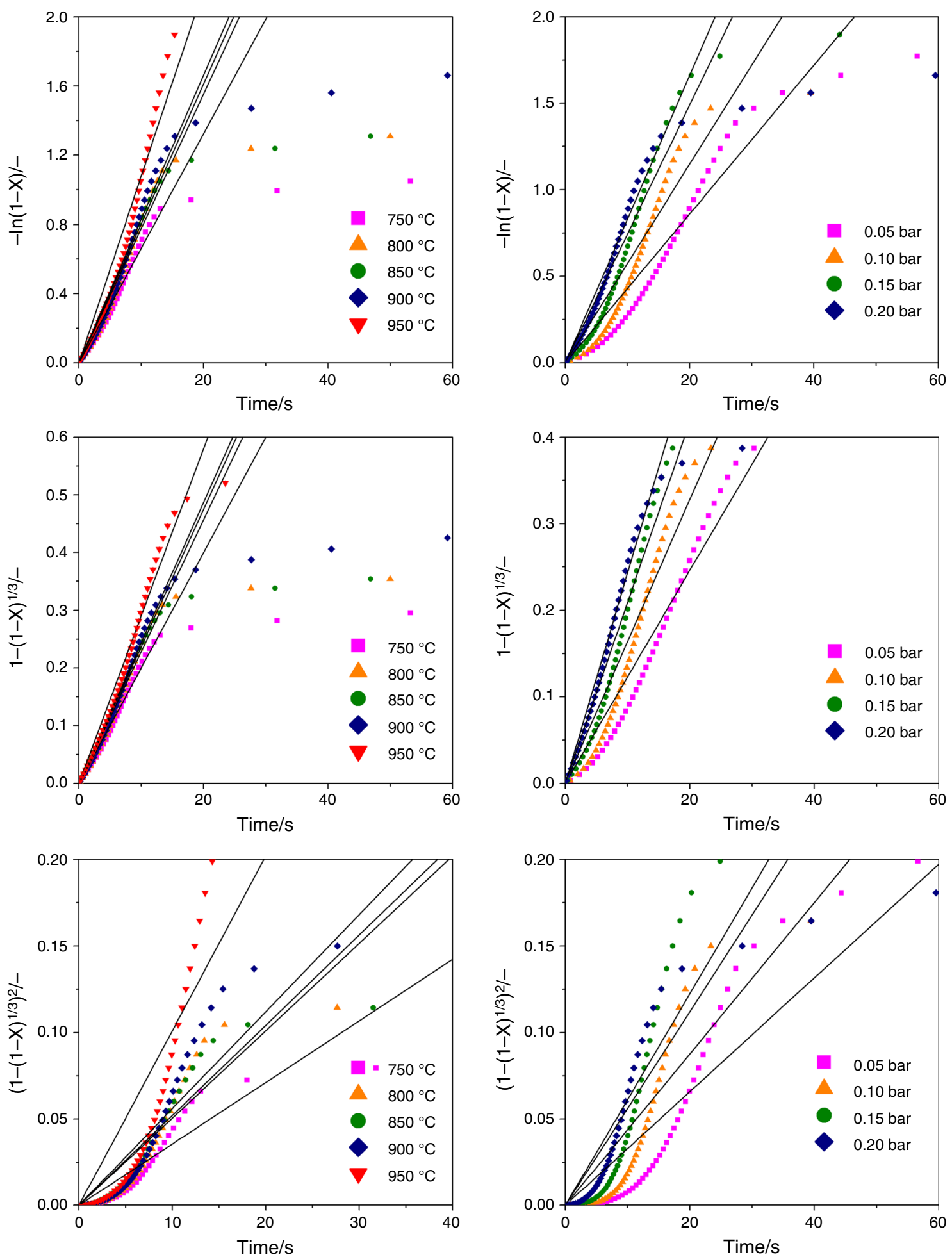

Fig. 10 Model fitting for the oxidation reaction for different temperatures and different $\mathrm{O}_{2}$ partial pressure 
Table 6 Oxidation reaction kinetics study for Kryvbas ore

\begin{tabular}{|c|c|c|c|c|c|c|}
\hline \multirow[t]{2}{*}{$\mathrm{T} /{ }^{\circ} \mathrm{C}$} & \multicolumn{2}{|l|}{ Model F1 } & \multicolumn{2}{|l|}{ Model R3 } & \multicolumn{2}{|l|}{ Model D3 } \\
\hline & $k / \mathrm{s}^{-1}$ & $R^{2}$ & $\mathrm{k} / \mathrm{s}^{-1}$ & $R^{2}$ & $\mathrm{k} / \mathrm{s}^{-1}$ & $R^{2}$ \\
\hline 750 & $6.620 \times 10^{-2}$ & 0.976 & $2.000 \times 10^{-2}$ & 0.987 & $3.560 \times 10^{-3}$ & 0.795 \\
\hline 800 & $7.760 \times 10^{-2}$ & 0.970 & $2.280 \times 10^{-2}$ & 0.985 & $5.050 \times 10^{-3}$ & 0.790 \\
\hline 850 & $8.040 \times 10^{-2}$ & 0.995 & $2.370 \times 10^{-2}$ & 0.997 & $5.210 \times 10^{-3}$ & 0.857 \\
\hline 900 & $8.300 \times 10^{-2}$ & 0.970 & $2.430 \times 10^{-2}$ & 0.987 & $5.600 \times 10^{-3}$ & 0.789 \\
\hline 950 & $1.079 \times 10^{-1}$ & 0.953 & $2.900 \times 10^{-2}$ & 0.980 & $1.010 \times 10^{-2}$ & 0.788 \\
\hline
\end{tabular}

Kinetics study

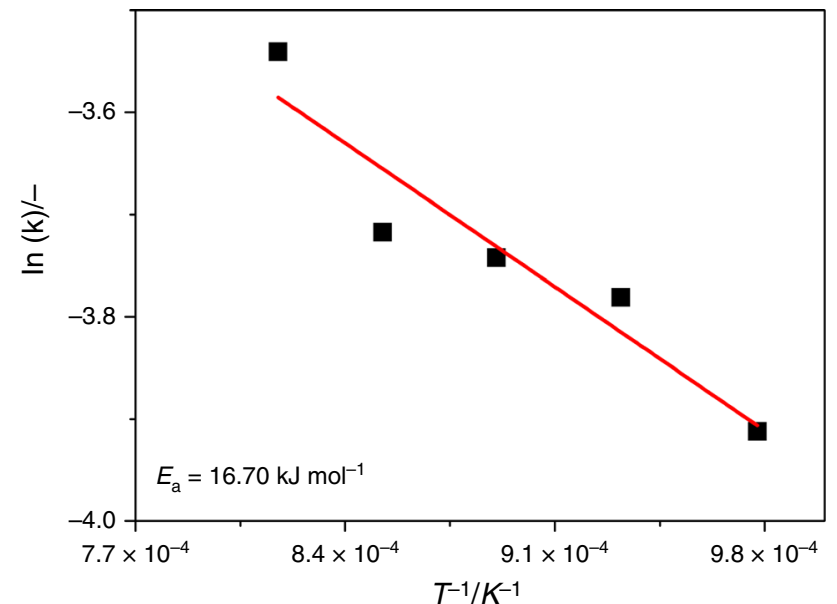

Fig. 11 Arrhenius plot of the oxidation reaction for applied model R3

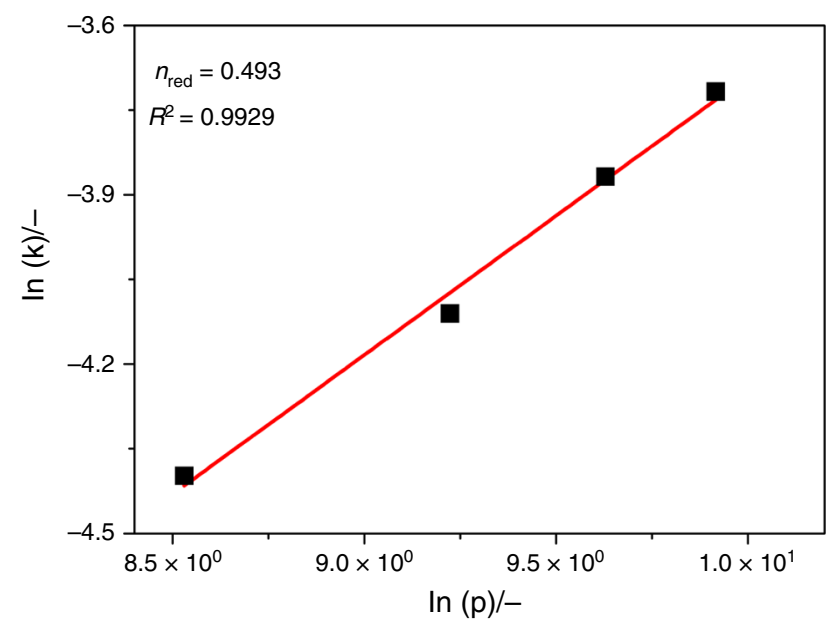

Fig. 12 Oxidation reaction order determination

To recap the results of the kinetics study, the calculated activation energy for the reduction reaction was $42.00 \mathrm{~kJ} \mathrm{~mol}^{-1}$ for the $\mathrm{F} 1$ model and for the oxidation reaction, it was equal to $16.70 \mathrm{~kJ} \mathrm{~mol}^{-1}$ for the $\mathrm{R} 3$ model; these models were the models that best fit the data.

\section{Conclusions}

In this study, the kinetics of the reduction and oxidation reactions for a naturally occurring Fe-based oxygen carrier were examined. The determination of the kinetic parameters based upon the performances of the Fe-based carriers is extremely important for the use of these carriers in real applications. The kinetic parameters obtained as a result of the study of the redox reactions of potentially suitable oxygen carriers might be useful for the designing of CLC reactors, as well as for the modeling of the systems. Tests were performed under isothermal conditions (750-950 ${ }^{\circ} \mathrm{C}$ ) for multiple redox cycles using an pressurized thermogravimetric analyzer. The activation energies, the pre-exponential factors, and the reaction orders were determined. The results showed that the F1 (volumetric) model was suitable for the reduction reaction of the Kryvbas ore, and the activation energy and the reaction order with respect to partial pressure of $\mathrm{CH}_{4}$ were calculated to be $42.00 \mathrm{~kJ} \mathrm{~mol}^{-1}$ and approximately 1.98 , respectively.

For the oxidation reaction of the Kryvbas ore, the R3 model demonstrated the best correlation with the data, and the activation energy and the reaction order were calculated to be $16.70 \mathrm{~kJ} \mathrm{~mol}^{-1}$ and approximately 0.49 , respectively.

Physicochemical characterizations of the ore samples, both the unreacted and the reacted revealed that the repetitive redox reactions did not affect the crystalline structure of the material. However, they did cause wearing away to the particles, and this can lead to a reduced mechanical stability of the material.

Based upon the obtained data, it may be concluded that the Kryvbas ore presents a good CLC performance: this is because stable oxygen transport capacity while cyclic redox reactions, and also due to its large oxygen transport capacity, which can be attributed to the presence of the highly concentrated hematite (above 80 mass \%).

The cost of the whole process can be reduced because a low inventory of carrier is needed to convert the fuel due to its high oxygen transfer capacity, as well as by the fact that the cost of the material itself is low because it is obtained 
from a naturally occurring ore and does not require any elaborate pretreatment procedures.

Acknowledgements This study was financed by The National Center of Research and Development Poland, Project No. NCBiR/ FENCO-NET2/2013, and the General Secretariat for Research and Technology Hellas, Project No. 13FENCO-13-478A "Minerals for Sustainable COst and energy efficient Chemical Looping Combustion Technology"-MINERAL SCOUT.

Open Access This article is distributed under the terms of the Creative Commons Attribution 4.0 International License (http://crea tivecommons.org/licenses/by/4.0/), which permits unrestricted use, distribution, and reproduction in any medium, provided you give appropriate credit to the original author(s) and the source, provide a link to the Creative Commons license, and indicate if changes were made.

\section{References}

1. Richter HJ, Knoche K. ACS symposium series 235. 1983.

2. Brandvoll O, Bolland O. J Eng Gas Turbines Power. 2004; $126: 316$.

3. Krongberger B, Lyngfelt A, Löffler G, Hofbauer H. Ind Eng Chem Res. 2005;44:546.

4. Ksepko E, Sciazko M, Babinski P. Studies on the redox reaction kinetics of $\mathrm{Fe} 2 \mathrm{O} 3-\mathrm{CuO} / \mathrm{Al} 2 \mathrm{O} 3$ and $\mathrm{Fe} 2 \mathrm{O} 3 / \mathrm{TiO} 2$ oxygen carriers. Appl Energy. 2014;115:374-83. doi:10.1016/j.apenergy.2013.10.064.

5. Liu W, Dennis JS, Scott SA. The effect of addition of $\mathrm{ZrO} 2$ to $\mathrm{Fe} 2 \mathrm{O} 3$ for hydrogen production by chemical looping. Ind Eng Chem Res. 2012;51(51):16597-609. doi:10.1021/ie302626x.

6. Zhao H-Y, Cao Y, Kang Z-Z, Wang Y-B, Pan W-P. Thermal characteristics of $\mathrm{Cu}$-based oxygen carriers. J Therm Anal Calorim. 2012;109(3):1105-9. doi:10.1007/s10973-011-2001-z.

7. Nalbandian L, Evdou A, Zaspalis V. La1-xSrxMyFe1-yO3- $\delta$ perovskites as oxygen-carrier materials for chemical-looping reforming. Int J Hydrogen Energy. 2011;36(11):6657-70. doi:10. 1016/j.ijhydene.2011.02.146.

8. Pishahang M, Bakken E, Stølen S, Larring Y, Thomas CI. Oxygen nonstoichiometry and redox thermodynamics of LaMn1-xCoxO3- $\delta$. Solid State Ionics. 2013;231:49-57. doi:10.1016/j.ssi.2012.10.009.

9. Nalbandian L, Evdou A, Holz D, Nikolaidou Z, Zaspalis V. Ferrites as RedOx catalysts for chemical looping and thermochemical water splitting processes. J Jpn Soc Powder Powder Metall. 2014;61(S1):S173-5. doi:10.2497/jjspm.61.S173.

10. Nalbandian L, Evdou A, Zaspalis V, editors. Ferrites as redox catalysts for chemical looping processes. 3rd International conference on chemical looping; 201409 11.09; Göteborg, Sweden.

11. Wang B, Xiao G, Song X, Zhao H, Zheng C. Chemical looping combustion of high-sulfur coal with $\mathrm{NiFe} 2 \mathrm{O} 4$-combined oxygen carrier. J Therm Anal Calorim. 2014;118(3):1593-602. doi:10. 1007/s10973-014-4074-y.
12. Wang B, Gao C, Wang W, Kong F, Zheng C. TGA-FTIR investigation of chemical looping combustion by coal with $\mathrm{CoFe} 2 \mathrm{O} 4$ combined oxygen carrier. J Anal Appl Pyrol. 2014;105:369-78. doi:10.1016/j.jaap.2013.12.002.

13. Son SR, Kim SD. Chemical-looping combustion with $\mathrm{NiO}$ and $\mathrm{Fe} 2 \mathrm{O} 3$ in a thermobalance and circulating fluidized bed reactor with double loops. Ind Eng Chem Res. 2006;45(8):2689-96. doi:10.1021/ie050919x.

14. Rydén M, Leion H, Mattisson T, Lyngfelt A. Combined oxides as oxygen-carrier material for chemical-looping with oxygen uncoupling. Appl Energy. 2014;113:1924-32. doi:10.1016/j.ape nergy.2013.06.016.

15. Leion H, Jerndal E, Steenari B-M, Hermansson S, Israelsson M, Jansson E, et al. Solid fuels in chemical-looping combustion using oxide scale and unprocessed iron ore as oxygen carriers. Fuel. 2009;88(10):1945-54. doi:10.1016/j.fuel.2009.03.033.

16. den Hoed P, Luckos A. Oxidation and reduction of iron-titanium oxides in chemical looping combustion: a phase-chemical description. Oil Gas Sci Technol Rev IFP Energ Nouv. 2011;66(2):249-63.

17. Jerndal E, Leion H, Axelsson L, Ekvall T, Hedberg M, Johansson $\mathrm{K}$ et al. Using low-cost iron-based materials as oxygen carriers for chemical looping combustion. Oil Gas Sci Technol Rev IFP Energ Nouv. 2011;66(2):235-48.

18. Huang Z, He F, Zhao K, Feng Y, Zheng A, Chang S, et al. Natural iron ore as an oxygen carrier for biomass chemical looping gasification in a fluidized bed reactor. J Therm Anal Calorim. 2014;116(3):1315-24. doi:10.1007/s10973-013-3630-1.

19. Ksepko E. Feasible utility of inorganic remains from potable water purification process in chemical looping combustion studied in TG. J Therm Anal Calorim. 2015;120(1):457-70. doi:10.1007/s10973-014-3973-2.

20. Ksepko E. Sewage sludge ash as an alternative low-cost oxygen carrier for chemical looping combustion. J Therm Anal Calorim. 2014;116(3):1395-407. doi:10.1007/s10973-013-3564-7.

21. Tian H, Siriwardane R, Simonyi T, Poston J. Natural ores as oxygen carriers in chemical looping combustion. Energy Fuels. 2013;27(8):4108-18. doi:10.1021/ef301486n.

22. Siriwardane RV, Ksepko E, Tian H, Poston J, Simonyi T, Sciazko $\mathrm{M}$. Interaction of iron-copper mixed metal oxide oxygen carriers with simulated synthesis gas derived from steam gasification of coal. Appl Energy. 2013;107:111-23. doi:10.1016/j.apenergy. 2013.01.063.

23. Abad A, García-Labiano F, de Diego LF, Gayán P, Adánez J. Reduction kinetics of $\mathrm{Cu}-, \mathrm{Ni}-$, and Fe-based oxygen carriers using syngas $(\mathrm{CO}+\mathrm{H} 2)$ for chemical-looping combustion. Energy Fuels. 2007;21(4):1843-53. doi:10.1021/ef070025k.

24. Cabello A, Abad A, García-Labiano F, Gayán P, de Diego LF, Adánez J. Kinetic determination of a highly reactive impregnated $\mathrm{Fe} 2 \mathrm{O} 3 / \mathrm{A} 12 \mathrm{O} 3$ oxygen carrier for use in gas-fueled chemical looping combustion. Chem Eng J. 2014;258:265-80. doi:10. 1016/j.cej.2014.07.083. 